ISSN 2078-6441. Вісник Львівського університету. Серія географічна. 2013. Випуск 44. С. 250-256. Visnyk of the Lviv University. Series Geography. 2013. Issue 44. P. 250-256.

$631.4(477)$

\title{
рій нойко
}

іровогр дський держ вний пед гогічний університет імені олодимир инниченк , вул. евченк , 1, 25006, м. іровогр д, кр їн

озкрито н йв жливіші морфологічні, г логеохімічні особливості т з кономірності поширення солонч ків 3 пл в межиріччя ніпро- олочн н підст ві н лізу результ тів вл сних польових досліджень втор .

лючові слов : солонч ки, з пл в , морфолого-г логеохімічні особливості, з кономірності поширення, межиріччя ніпро- олочн .

огляду н в жливу л ндш фтоформув льну роль 3 пл вних солонч ків пит ння, які стосуються дослідження їхніх морфолого-г логеохімічних особливостей т 3 кономірностей поширення, є н дзвич йно кту льними. творення л ндш фтного, земельного к д стру, вжиття природоохоронних з ходів, екологічного моніторингу, к ртогр фічних робіт потребує дет льного вивчення всього генетичного різном ніття цих грунтів у меж х території кр їни. роте особливості формув ння, морфологічн будов т г логеохімічні вл стивості з пл вних солонч ків окремих регіонів кр їни, зокрем межиріччя ніпр - олочної, сьогодні ще недост тньо вивчені.

еякі спекти формув ння, окремі морфологічні т фізико-хімічні вл стивості з пл вних солонч ків межиріччя ніпр - олочної висвітлені в пр цях . едорищ к , ря т . ищенк [3], . ищенк [4], ч стково . хов [1]. жливу роль у досліджені солонч ків півдня кр їни відігр в . их йлюк [2]. чений н прикл ді регіону івнічно- хідного ричорномор'я в кл сифік ції грунтів річкових 3 пл в виділив групу з пл вних солонч ків. дослідженнях · их йлюк (2001) головними ді гностичними горизонт ми у р зі кл сифік ції з пл вних солонч ків були солонч ковий, темногумусовий структуров ний (зернистий), ясногумусовий сл бкоструктуров ний, злитий, глейовий, криптоглейовий т мулув тий генетичні горизонти.

и протягом 2007-2012 рр. проводили польові т л бор торно- н літичні дослідження з пл вних солонч ків межиріччя ніпр - олочної, зокрем , дет льно вивч ли 3 кономірності поширення, морфологічні т г логеохімічні особливості цих грунтів.

пл вні солонч ки межиріччя ніпр - олочної $є$ результ том процесів солен копичення в умов х 3 пл вних геокомплексів річкових долин. осліджув н груп грунтів утворюється перев жно н легких 3 гр нулометричним скл дом люві льних відкл д х річкових з пл в, з неглибокого рівня з ляг ння мінер лізов них грунтових вод (0,5-1,5 м), в меж х гирлових ч стин рік - т кож у р зі деякого впливу морських водно-сольових розчинів. Йв жливішими чинник ми, які визн ч ють особливості формув ння з пл вних солонч ків у регіоні, є мінер лізов ні грунтові води, рельєФ т гр нулометрія грунтоутворюв льних порід. олонч ки, які утворилися в меж х н йбільше підвищених ділянок з пл в н гр нулометрично легких відкл д х, вирізня-

(C) нойко ., 2013 
ються порівняно не н дто високими ступенями з соленості грунто-підгрунтя, т , досить ч сто, чергув нням процесів інтенсивного з солення і розсолення грунтового профілю. олонч ки знижених ділянок 3 пл в формуються перев жно н в жчих 3 гр нулометричним скл дом відкл д $\mathrm{x}$ в умов х здебільшого н копичув льного б л нсу речовини $і$ в цьому р зі м ють н йвищі ступені з соленості т КТивно- кумулятивний генетичний тип з соленості профілю.

йбільші м сиви з пл вних солонч ків досліджув ної території утворилися в дельті ніпр, у з пл в х гирлових т пригирлових ч стин річкових долин олочної, л нч к, еликого і лого тлюк, тм н я т деяких інших м лих рік. рунтові води в т ких умов х, з звич й, з ляг ють н йближче до поверхні, їхня мінер ліз ція є н йвищою порівняно з грунтовими вод ми з пл ви річкової долини в середній т верхній течії. н чні площі $з$ пл вних солонч ків у гирлових ділянк х річкових долин т кож пов'яз ні з незн чним природним дрен жем сформов них тут геокомплексів т впливом морських водно-сольових розчинів, які н дходять сюди із солоних лим нів. рім того, н йч стіше площі під з пл вою зн чно більші в нижній течії річки, ніж у їі верхів ї т середній ч стині. Г лом же н ведені вище умови солен гром дження зумовлюють збільшення площ 3 пл вних солонч ків униз з течією.

в меж х приморських низовин, і н території річкових 3 пл в н віть порівняно незн чні зміни в гіпсометричному рівні можуть визн чити специфіку водно-сольового режиму грунту т зумовлюв ти формув ння г логенних грунтів. йч стіше 3 пл вні солонч ки утворюються в меж х низинних сл бкодренов них ділянок центр льної т притер сної ч стини з пл ви (менше це стосується прируслової з пл ви). олонч ки з пл вні темногумусові формуються н вирівняних чи знижених, перев жно відд лених від прируслової ч стини місцях з пл ви, тобто в умов х, н йбільш сприятливих для розвитку процесу гумусоутворення т гумусон гром дження. сногумусові солонч ки утворюються н підвищених ділянк х 3 пл ви 3 домінув нням гр нулометрично легких люві льних відкл дів. ля еволюційно молодих солонч ків прируслової ч стини $з$ пл ви х р ктерн н йсл бш диференці ція грунтового профілю, 3 г льн примітивність будови, незн чн потужність профілю, ш рув тість структури. олонч ки з пл вні у грунтовому покриві з пл в н йч стіше формують комплекси 3 люві льними лучно-болотними т люві льними лучними грунт ми, дешо рідше - 3 люві льними дерновими грунт ми.

пл вні солонч ки межиріччя ніпр - олочної формуються перев жно в умов х 3 пл вно-дельтових т з пл вно-пл вневих л ндш фтних комплексів олоприст нського з пл вного, інбурнського приморсько- ренного, л нч цького приморськоз п динного, тлюцько- озув тського приморсько-долинного т отієвського флюві льно-рівнинного фізико-геогр фічних р йонів.

ослинний покрив з пл вних солонч ків різном нітніший, ніж рослинність приморських солонч ків, і, крім типових г лофітів ( соці ції солеросів, с рс з ну, кермеку), предст влений б г тьм зл ковими рослин ми. трок тіший видовий скл д рослинності 3 пл вних солонч ків пов'яз ний передусім із дещо меншим ступенем 3 соленості їхніх поверхневих горизонтів порівняно з з соленістю приморських солонч ків.

ех нічний скл д 3 пл вних солонч ків н йч стіше піщ ний т супіщ ний (див. т бл. 1), що зумовлено формув нням цих грунтів н “легких" люві льних відкл д х річкових долин.

відміну від солонч ків шороподібних з п дин межиріччя ніпр - олочної, грунтовий профіль солонч ків з пл в більше диференційов ний н генетичні горизон- 
ти. ольов кірк утворюється перев жно н поверхні солонч ків, які сформув лися в меж х днищ i нижніх ч стин схилів мікроз п дин т улоговин річкових 3 пл в 3 н йближчим до поверхні рівнем з ляг ння мінер лізов них грунтових вод.

блиця 1

р нулометричний скл д з пл вних солонч ків межиріччя ніпр - олочної

\begin{tabular}{|c|c|c|c|c|c|c|c|c|c|}
\hline \multirow{2}{*}{ оризонт } & \multicolumn{7}{c|}{ озподіл ч сток, \%, по фр кціях, мм } & \multicolumn{2}{c|}{ ум ч сток } \\
\cline { 2 - 9 } & $0,50-0,25$ & $0,25-0,10$ & $0,10-0,05$ & $0,05-0,01$ & $0,01-0,005$ & $<0,005$ & $>0,01$ & $<0,01$ \\
\hline \multicolumn{8}{|c|}{ олонч к з пл вний кірковий ясногумусов ний сульф тно-хлоридний глейовий супіщ ний } \\
(днище мікрозниження в дельті ніпр ) \\
\hline Sk & 2 & 3 & 13 & 58 & 5 & 19 & 76 & 24 \\
\hline HEsk & 4 & 8 & 51 & 17 & 6 & 14 & 80 & 20 \\
\hline РGlks & 7 & 7 & 55 & 8 & 5 & 18 & 77 & 23 \\
\hline \multicolumn{8}{|c|}{ олонч к з пл вний кірковий ясногумусов ний сульф тно-хлоридний глеюв тий піщ ний } \\
\hline (верхня третин схилу улоговини в меж х дельти ніпр ) \\
\hline Sk & 22 & 40 & 22 & 3 & 3 & 10 & 87 & 13 \\
\hline HEsk & 38 & 36 & 21 & 2 & 1 & 2 & 97 & 3 \\
\hline Phikgl & 26 & 48 & 19 & 3 & 1 & 3 & 96 & 4 \\
\hline Pkgl & 18 & 57 & 19 & 3 & 1 & 2 & 97 & 3 \\
\hline PGlk & 11 & 38 & 20 & 12 & 8 & 11 & 81 & 19 \\
\hline
\end{tabular}

ля з пл вних солонч ків підвищених геокомплексів сольов кірк не $є$ х р ктерним морфологічним елементом. Звич й, у грунтовому профілі солонч ків 3 пл в добре вир жений досить потужний ясно- бо темногумусовий горизонт $(0,05-0,10$ м). емногумусові з пл вні солонч ки межиріччя формуються перев жно н підвищених ділянк $\mathrm{x}$ річкових з пл в 3 порівняно глибоким рівнем грунтових вод під зл ковог лофітною рослинністю. сногумусові солонч ки утворюються звич йно в різном нітних депресіях річкових з пл в під зрідженим г лофітним рослинним покривом. міст гумусу в орг ногоризонт х досліджув них з пл вних солонч ків для ясногумусових ст новив близько 1-2 \%, для темногумусових - перев жно 2,9-3,5 \%.

оризонти, які формуються в середній т нижній ч стин х грунтового профілю солонч ків з пл в вирізняються оглеєністю, утворенням великих скупчень з лізом нг нових новоутворень, плямистістю, липкістю, інколи в'язкістю. лізо-м нг нові новоутворення в профілі з пл вних солонч ків предст влені у вигляді темно-бурих плям, зерен, конкрецій т бобовин. сто в меж х перехідного горизонту простежується деяке підтік ння гумусу з приповерхневих гумусових горизонтів.

собливості морфологічної будови солонч ків з пл вних ясногумусових глейових ми вивч ли н прикл ді розрізу, зробленого в з пл ві пониззя ніпр поблизу c. олонці в меж х днищ мікроз п дини під рослинним покривом із солеросів i с рс з ну. рофіль досліджув ного грунту предст влений т кими генетичними горизонт ми:

Sk (0,00-0,02 м) - поверхнев сольов кірк , біляст , доволі потужн , суцільн , крихк , розбит невеликими тріщин ми н окремі ч стинки;

HEsk $(0,02-0,08$ м) - ясногумусов ний горизонт сірого т ясно-сірого з 6 рвлення (темніше з б рвлення м є верхня ч стин горизонту до глибини 0,05 м), супіщ ний, сл бколипкий, вологув тий, прониз ний корінням рослин, 3 глибини 0,05 м з'являються добре помітні скупчення крист лів легкорозчинних солей, чітк хвиляст нижня меж ; 
Phiskgl (0,08-0,21 м) - перехідний горизонт темно-сірого (місцями до чорного) з 6 рвлення, супіш ний, липкий, вологув тий, оглеєний, у верхній ч стині до глибини 0,16 м простежується підтік ння гумусу т зн чні скупчення новоутворень легкорозчинних солей у вигляді прожилок, чітк нижня меж ;

PGlks (> 0,21 м) - глейовий горизонт оливкового з б рвлення, супіщ ний, оглеєний, дуже липкий, вологий, з глибиною в'язкий т мокрий.

івень грунтових вод $-0,65$ м. урхливе з кип ння з поверхні.

ля темногумусових з пл вних солонч ків, які формуються, з звич й, у меж х підвищених ч стин річкових з пл в досліджув ної території, х р ктерні потужніший гумусовий горизонт, відсутність суцільної поверхневої сольової кірки, порівняно незн чн оглеєність нижньої ч стини профілю. орфологію солонч ків з пл вних темногумусових глеюв тих проілюструємо розрізом, який з кл дено поряд з попереднім у меж х верхньої третини схилу мікроз п дини під густим тр востоєм із солеросів, кермеку і різном нітних зл кових.

HEs $(0,00-0,07$ м) - темногумусовий горизонт (місцями з вицвіт ми солей н поверхні у вигляді присипок і псевдоміцелію, які утворюють фр гмент рну, м лопотужну крихку кірку), темно-сірого з б рвлення, супіщ ний, сл бколипкий, вологув тий, у верхній ч стині прониз ний корінням рослин, візу льно добре помітні скупчення крист лів легкорозчинних солей, зубч ст нижня меж ;

Phiskr (0,07-0,32 м) - перехідний горизонт, темно-сірого і сірого з б рвлення, піщ ний, сл бколипкий, вологув тий, у верхній ч стині простежуються підтік ння гумусу, у нижній ч стині $(0,26-0,32$ м) б г то скупчень з лізо-м нг нових новоутворень, перев жно у вигляді плям бурого і чорного кольору, поступовий нижній перехід;

Pglkn (> 0,32 м) - глеюв тий горизонт, світло-сірий і сірий пісок, вологув тий, 3 глибиною вологий, плямистий, б г то з лізо-м нг нових конкрецій, у нижній ч стині сл бкооглеєний, що візу льно виявляється у появі плям оливкового кольору.

івень грунтових вод $-0,85$ м. кип є 3 поверхні.

осліджув ні з пл вні солонч ки межиріччя ніпр - олочної вирізняються доволі зн чним вмістом к рбон тів. ксим льн кількість к рбон тів х р ктерн для ясногумусових солонч ків, які формуються в меж х н йбільш знижених ділянок 3 пл ви. т ких умов вміст к рбон тів у поверхневих горизонт х ст новить близько 7-9 \%, у нижніх горизонт х $-16-21 \%$. емногумусові з пл вні солонч ки кумулюють у грунтовому профілі зн чно меншу кількість к рбон тів - 0,84-1,26\% у верхній ч стині т 2,10-3,36 \% у нижній ч стині профілю.

ксим льні зн чення ємності к тіонного обміну з пл вних солонч ків х р ктерні для поверхневих горизонтів супіш них різновидів цих грунтів 49,39-139,54 мг-екв/100 гр., мінім льні - для піщ них горизонтів у нижній ч стині грунтового профілю (2,26-7,41 мг-екв/100 гр.). ередні зн чення ємності вбир ння досліджув них грунтів колив ються в меж х 36,04-49,39 мг-екв/100 гр., що зн чно вище, ніж для приморських солонч ків, одн к нижче від н логічних пок зників солонч ків шороподібних з п дин межиріччя. вбирному комплексі солонч ків 3 пл в (див. т бл. 2) перев ж ють к тіони н трію, вміст яких може досяг ти 84,63-97,39 \% від 3 г льної суми вбирних к тіонів у меж х поверхневих н йбільш з солених горизонтів.

стк поглинутих к тіонів к льцію і м гнію у грунтово-вбирному комплексі з пл вних солонч ків, з звич й, зрост є 3 глибиною: від 1,10-8,28 мг-екв/100 гр. для к льцію т 1,51-7,09 мг-екв/100 гр. для м гнію у верхній ч стині грунтового профілю і до 4,0319,78 т 31,06-73,10 мг-екв/100 гр., відповідно, в середній і нижній ч стин х профілю. 
кл д грунтового вбирного комплексу з пл вних солонч ків межиріччя ніпр - олочної

\begin{tabular}{|c|c|c|c|c|c|c|c|}
\hline \multirow[t]{2}{*}{ оризонт } & \multirow{2}{*}{$\begin{array}{c}\text { ум вбирних } \\
\text { к тіонів, } \\
\text { мг-екв/100гр. }\end{array}$} & \multicolumn{3}{|c|}{$\begin{array}{l}\text { бирні к тіони, } \\
\text { мГ-екв/100 гр. }\end{array}$} & \multicolumn{3}{|c|}{$\begin{array}{l}\text { бирні к тіони, } \\
\text { \% від суми }\end{array}$} \\
\hline & & $\mathrm{Ca}^{2+}$ & $\mathrm{Mg}^{2+}$ & $\mathrm{Na}^{+}$ & $\mathrm{Ca}^{2+}$ & $\mathrm{Mg}^{2+}$ & $\mathrm{Na}^{+}$ \\
\hline \multicolumn{8}{|c|}{$\begin{array}{c}\text { олонч к з пл вний безкірковий темногумусов ний хлоридний глеюв тий супіщ ний } \\
\text { (мікропідвищення в меж х дельти ніпр ) }\end{array}$} \\
\hline $\mathrm{HEs}$ & 136,47 & 2,35 & 6,00 & 128,12 & 1,72 & 4,40 & 93,88 \\
\hline Phiskr & 49,39 & 4,09 & 3,50 & 41,80 & 8,28 & 7,09 & 84,63 \\
\hline Pglkn & 7,41 & 1,31 & 3,34 & 2,76 & 17,68 & 45,07 & 37,25 \\
\hline Pglk & 5,56 & 1,10 & 2,40 & 2,06 & 19,78 & 43,17 & 37,05 \\
\hline \multicolumn{8}{|c|}{$\begin{array}{c}\text { олонч к з пл вний кірковий ясногумусов ний сульф тно-хлоридний глейовий супіщ ний } \\
\text { (днище мікрозниження в дельті } \text { ніпр ) }\end{array}$} \\
\hline Sk & 139,54 & 1,53 & 2,11 & 135,90 & 1,10 & 1,51 & 97,39 \\
\hline HEsk & 41,19 & 1,34 & 1,87 & 37,98 & 3,24 & 4,54 & 92,22 \\
\hline PGlks & 43,64 & 1,26 & 1,48 & 40,90 & 2,89 & 3,39 & 93,72 \\
\hline PGlk & 16,10 & 2,26 & 5,00 & 8,44 & 14,03 & 31,06 & 54,91 \\
\hline \multicolumn{8}{|c|}{$\begin{array}{c}\text { олонч к з пл вний кірковий ясногумусов ний сульф тно-хлоридний глеюв тий піщ ний } \\
\text { (верхня третин схилу улоговини в меж х дельти ніпр ) }\end{array}$} \\
\hline $\mathrm{Sk}$ & 36,04 & 23,57 & 4,25 & 8,22 & 65,40 & 11,80 & 22,80 \\
\hline HEsk & 11,60 & 1,45 & 4,75 & 5,40 & 12,50 & 40,95 & 46,55 \\
\hline Phikgl & 10,48 & 0,16 & 7,66 & 2,66 & 1,53 & 73,10 & 25,37 \\
\hline Pkgl & 2,26 & 0,15 & 1,15 & 0,96 & 6,64 & 50,89 & 42,47 \\
\hline PGlk & 5,03 & 0,13 & 1,55 & 3,35 & 2,58 & 30,82 & 66,60 \\
\hline
\end{tabular}

е кція грунтового розчину з пл вних солонч ків, які досліджув ли, сл бколужн т близьк до нейтр льної. н чення $\mathrm{p}$ для цих грунтів змінюв л сь у доволі широких меж x - від 6,8 і до 8,4. цьому р зі середні пок зники р ст новлять 7,1-7,6. глибиною ре кція з пл вних солонч ків змінюється по-різному.

пл вні солонч ки межиріччя ніпр - олочної м ють грибоподібний морфологічний тип сольового профілю з високою концентр цією легкорозчинних солей у верхній ч стині профілю т зн чно меншим їхнім вмістом у середній і нижній ч стин х. оверхнев сольов кірк з пл вних солонч ків уміщує близько 7,74-10,79\% токсичних солей, вміст яких 3 глибиною різко зменшується до 1,09-5,32 \% у меж х приповерхневого солонч кового горизонту, т $0,19-0,69 \%$ в нижніх горизонт х (див. т бл. 3). тже, якщо поверхневі горизонти з пл вних солонч ків досліджув ної території є дуже сильноз соленими, то їхні нижні горизонти н йч стіше м ють середній т сильний ступені 3 соленості. омін нтним хімічним типом 3 соленості солонч ків з пл в є хлоридний тип, субдомін нтним - сульф тно-хлоридний.

тже, сформулюємо низку в жливих висновків щодо з кономірностей поширення, морфології т г логеохімічних особливостей з пл вних солонч ків межиріччя ніпр олочної:

- 3 пл вні солонч ки межиріччя ніпр - олочної утворюються в умов х 3 пл вних геокомплексів річкових долин і вн слідок недост тньо розвиненої гідрогр фічної мережі регіону дослідження з йм ють порівняно незн чні площі; 
сновні пок зники з соленості з пл вних солонч ків межиріччя ніпр - олочної

\begin{tabular}{|c|c|c|c|c|c|c|c|c|c|c|c|}
\hline \multirow{2}{*}{ оризонт } & \multirow[b]{2}{*}{$\mathrm{p}$} & \multicolumn{3}{|c|}{$\begin{array}{c}\text { етоксичні іони, } \\
\text { мг-екв/100 гр. грунту }\end{array}$} & \multicolumn{5}{|c|}{$\begin{array}{c}\text { оксичні іони, } \\
\text { мг-екв/ } 100 \text { гр. грунту }\end{array}$} & \multirow{2}{*}{$\begin{array}{c}\text { ум } \\
\text { токсич- } \\
\text { ності } \\
\text { солей, } \\
\%\end{array}$} & \multirow{2}{*}{$\begin{array}{c}\text { тупінь } \\
\text { і тип } \\
\text { з соле- } \\
\text { ності }\end{array}$} \\
\hline & & + & $\mathrm{HCO}_{3}$ & $\mathrm{SO}_{4}^{-}$ & $\mathrm{SO}_{4}^{-}$ & $\mathrm{Cl}^{-}$ & + & $\mathrm{Mg}^{2+}$ & $\mathrm{Na}^{+}+\mathrm{K}^{+}$ & & \\
\hline
\end{tabular}

олонч к 3 пл вний кірковий ясногумусов ний сульф тно-хлоридний глеюв тий піщ ний (верхня третин схилу улоговини в меж х дельти ніпр )

\begin{tabular}{|c|c|c|c|c|c|c|c|c|c|c|c|}
\hline Sk & 8,4 & 36,25 & 0,60 & 35,65 & 47,09 & 127,5 & - & 23,75 & 151,3 & 10,790 & $5 \mathrm{C}$ \\
\hline HEsk & 7,8 & 1,75 & 0,40 & 1,35 & 3,74 & 12,00 & - & 3,25 & 12,49 & 1,089 & 5 \\
\hline Phikgl & 8,2 & 0,96 & 0,32 & 0,64 & 2,03 & 8,10 & - & 3,54 & 6,59 & 0,613 & 4 \\
\hline Pkgl & 7,8 & 1,25 & 0,40 & 0,85 & 2,81 & 8,60 & - & 3,25 & 8,16 & 0,698 & 4 \\
\hline PGlk & 7,5 & 1,85 & 0,38 & 1,47 & 4,18 & 13,50 & - & 6,05 & 11,63 & 1,077 & 5 \\
\hline
\end{tabular}

олонч к 3 пл вний кірковий ясногумусов ний сульф тно-хлоридний глейовий супіщ ний (днище мікрозниження в дельті ніпр )

\begin{tabular}{|c|c|c|c|c|c|c|c|c|c|c|c|}
\hline Sk & 6,9 & 2,39 & 1,06 & 1,33 & - & 136,3 & 15,11 & 20,00 & 101,0 & 7,739 & 5 \\
\hline HEsk & 6,8 & 11,50 & 0,50 & 11,00 & 14,26 & 34,00 & - & 7,50 & 40,76 & 2,926 & 5 \\
\hline PGlks & 7,1 & 6,50 & 0,78 & 5,72 & 6,38 & 39,50 & - & 8,00 & 37,88 & 2,683 & 5 \\
\hline PGlk & 7,4 & 2,70 & 0,56 & 2,14 & 13,87 & 10,50 & - & 2,10 & 22,27 & 1,580 & 5 \\
\hline \multicolumn{10}{|c|}{ олонч к з пл вний безкірковий темногумусов ний хлоридний глеюв тий супіщ ний } \\
(мікропідвищення в меж х дельти ніпр ) \\
\hline HEs & 7,6 & 17,00 & 1,46 & 15,54 & 0,64 & 95,00 & - & 27,00 & 68,64 & 5,323 & 5 \\
\hline Phiskr & 7,2 & 1,75 & 0,64 & 1,11 & 2,23 & 50,00 & - & 6,50 & 45,73 & 3,020 & 5 \\
\hline Pglkn & 7,4 & 0,58 & 0,58 & - & 0,24 & 4,70 & - & 0,66 & 4,30 & 0,288 & 3 \\
\hline Pglk & 7,5 & 0,01 & 0,54 & 0,29 & - & 3,35 & 0,21 & 0,60 & 2,54 & 0,190 & 3 \\
\hline
\end{tabular}

- формуються з пл вні солонч ки в меж х низинних сл бодренов них ділянок центр льної чи прируслової з пл ви, здебільшого в гирловій т пригирловій ч стин х річкових долин ніпр, олочної, л нч К, еликого і лого тлюк, тм н я, деяких інших м лих рік, н люві льних т люві льно-делюві льних відкл д х;

- визн ч льними педог логенними чинник ми утворення 3 пл вних солонч ків межиріччя ніпр - олочної є мінер лізов ні грунтові води, рельєф і гр нулометричний скл д грунтоутворюв льних порід, в приморській ч стині гирл рік - і морські водно-сольові розчини;

- ді гностичними горизонт ми з пл вних солонч ків межиріччя є солонч ковий (сольов кірк утворюється зрідк), ясно- чи темногумусовий т глейові горизонти з різним ступенем оглеєності;

- солонч ки з пл вні досліджув ної території м ють високу в рі бельність різке домінув ння у вбирному комплексі іонів н трію, м ксимум легкорозчинних солей у приповерхневих горизонт х, перев жне хлоридне т субдомін нтне сульф тнохлоридне з солення, перев жно грибоподібний сольовий профіль.

\section{СПИСОК ВИКОРИСТАНОЇ ЛІТЕРАТУРИ}

1. хов . . гровиробнич х р ктеристик грунтів зони б вовносіяння / . . хов // руди кр. н.-д. ін-ту соці лістичного землеробств .- иїв; олт в 1937. - .3. $-144 \mathrm{c}$. 
2. ux йлюк . . рунти долин річок північно-з хідного ричорномор'я: екологія, генез, систем тик , вл стивості, проблеми використ ння : моногр фія / . . их йлюк. - дес : стропринт, 2001. - 340 с.

3. едорищ к . . торичное з соление почв дельты непр / . . едорищ к, . .

4. ищенко . . рикл дн я физическ я геогр фия / . . ищенко. - иев : ищ шк., 1988. - 192 с.

m ття:н дійшл до ред кцї̈ 07.05.2013

доопр иьов н 03.06 .2013

прийнят до друку 17.06.2013

\section{MORPHOLOGIC-GALOGEOCHEMICAL ASPECTS AND PECULIARITIES OF ENLARGING OF SALINE SOILS OF FLOODPLAINS OF INTERFLUVES OF DNIPRO-MOLOCHNA RIVERS}

\section{Yuriy Onoyko}

Vynnychenko State Pedagogical University of Kirovorad, Shevchenko St., 1, UA - 25006, Kirovograd, Ukraine

It is defined the most important morphological, galogeochemical aspects and peculiarities of enlarging of saline soils of floodplains of interfluves of Dnipro-Molochna Rivers on the basis of analysis of results of the author's field researches.

Key words: saline soils, drown lands, morphologic-galogeochemical peculiarities, aspects of enlarging, within bounds of Dnipro-Molochna.

\section{рий нойко}

ировогр дский госуд рственный пед гогический университет имени л димир инниченко, ул. евченко, 1, 25006, г. ировогр д, кр ин

скрыто н иболее в жные морфологические, г логеохимические особенности и з кономерности р спростр нения солонч ков пойм междуречья непр- олочн я н основ нии н лиз результ тов собственных полевых исследов ний втор .

лючевые слов : солонч ки, пойм , морфолого-г логеохимические особенности, з кономерности р спростр нения, междуречье непр- олочн я. 